\title{
Negative governmentality through fundamental rights: The far side of the European Convention on Human Rights
}

\author{
Muhammad Ali Nasir* (D)
}

\begin{abstract}
This essay analyses those statements that mention legal norms in negative terms. Specifically, it analyses those statements that define a legal system by mentioning how legal protection does not work and where legal protection ends, and those statements that identify what rights-holders do not have to with their legally protected free capacities. This essay argues that these statements address a systemic question. It calls such a dynamic as negative governmentality. The argument proceeds in four steps. It introduces the concept of negative governmentality by arguing that the idea of freedom requires both the positive affirmation of moral agency and the constraining of moral agency (Section 2). It then explores how rights constitute freedom by limiting rights or making exceptions to them (Section 3). Later, it analyses how rights-based norms prevent abuse of rights by holders of rights (Section 4). Finally, it sees how rights-based norms constrain the legal guarantor of rights, i.e., a state (Section 5). The essay concludes by mentioning the importance of negative governmentality (Section 6).
\end{abstract}

The nature of an use is best discerned by considering first, what it is not; and then what it is: for it is the nature of all human science and knowledge to proceed most safely by negative and exclusion, to what is affirmative and inclusive.

Francis Bacon, On the Statute of Uses ${ }^{1}$

The concept of freedom is a pure concept of reason. It does not constitute an object of any theoretical knowledge that is possible for us; and it can by no means be valid as a constitutive principle of speculative reason, but can be valid only as a regulative and, indeed, merely negative principle of speculative reason.

Immanuel Kant, Introduction to the Metaphysics of Morals ${ }^{2}$

\footnotetext{
"PhD Candidate, Institut für Politische Wissenschaft, Ruprecht-Karls-Universität Heidelberg, Heidelberg, Germany. I am grateful to Mark Tushnet, Tom Poole, and Michael Haus for their comments on an earlier version of this essay. Special thanks are due to the anonymous reviewers and, particularly to Agustín José Menéndez, the editor, of the European Law Journal for their useful feedback at every stage of writing. The usual disclaimer applies.

${ }^{1}$ J. Spedding, R.L. Ellis and D. D. Heath (eds.), The Works of Francis Bacon (Houghton, 1857), at VII: 398.

${ }^{2}$ I. Kant, Metaphysical Elements of Justice (first published 1797, Hackett 1999; translated by J. Ladd), at 14 (original emphasis).
} 


\section{1 | Introduction}

One of the key arguments of Jeremy Bentham against the French Declaration of Rights (the 1789 Declaration of the Rights of Man and of the Citizen) concerned the syntax of the document. The reader of the Declaration could easily be deluded into thinking that the rights enshrined in the text were virtually limitless, because no explicit reference was made to limits, restrictions and exceptions.

Suppose a declaration to this effect: No man's liberty shall be abridged in any point. This, it is evident, would be an useless extravagance, which must be contradicted by every law that came to be made. ${ }^{3}$

This is what justified Bentham's characterisation of the Declaration as 'nonsense upon stilts': 'This, we see, is nothing: It leaves the law just as free and unfettered as it found it'.4

One need not agree with Bentham's full theory of rights to be of the view that he had a point when he emphasised the importance of limits and restrictions in the full and proper definition of rights. Quoting Bentham again: 'No law can be made that does not take something from liberty; those excepted which take away, in the whole or in part, those laws which take away from liberty'. In other words, rights have to be set in their socio-economic and political context, something which requires focusing on the formally 'negative' side of rights, that is, on limitation clauses, exceptions and anti-abuse provisions. Limitations and restrictions not only render the definition complete, but also play a fundamental role in shaping and moulding the very understanding of rights entertained by rights-holders. It can thus be argued that fundamental rights play a key role in the governing of European societies, not only by affirming certain normative standards (and in the process producing normative knowledge) but also by deeply shaping the way in which the addressees of the law regard themselves and their environment.

In this article, I offer a systematic reconstruction of the 'negative' clauses of the European Convention on Human Rights, in particular its limitation and exception clauses (Section 3), its anti-abuse clause (Article 18, analysed in Section 4) and last, but not least, the clause that restricts the extent to which states can limit or except rights (Article 18, considered in Section 5). The next section is devoted to exploring the role of rights in the governing of European societies, in what, following Foucauldian terminology, we may refer to as 'negative governmentality', or, more precisely, as 'negative intergovernmentality'.

One methodological caveat. The article is written across disciplinary and substantive 'borders'. Quite obviously, the article speaks to debates in the literature on the European Convention on Human Rights, and more generally, about the protection of fundamental rights. The key claim in this regard, as already pointed out, is that proper understanding of the Convention rights depends on considering not only the 'positive' definition of rights, but also their 'negative side'. It is the latter, as just underlined, that provides an understanding of the systemic relationship between the different Convention rights, or to put it differently, a systemic reconstruction of the content of the Convention. At the same time, however, the article engages with the politico-scientific debates on governmentality, that is, with literature that focuses on the way conduct is governed. ${ }^{6}$ In particular, it seems to me that a legally-grounded analysis may contribute to filling a major gap in such (i.e., governmentality) analyses, i.e., the extent to which the shaping of

\footnotetext{
${ }^{3}$ J. Bowring (ed.), The Works of Jeremy Bentham (William Tait, 1843), at II: 493a.

${ }^{4}$ lbid.

${ }^{5}$ Bowring, above, n. 3, at II: 493b.

${ }^{6}$ E.g., M. Foucault, Security, Territory, Population: Lectures at the College de France 1977-1978 (Palgrave Macmillan, 2007); M.A. Nasir, 'Governing (through) Religion: Reflections on Religion as Governmentality', (2016) 42 Philosophy \& Social Criticism, 873; B. SokhiBulley, 'Government(ality) by Experts: Human Rights as Governance', (2011) 22 Law \& Critique, 251; M.A. Nasir, 'Weighing Words: On the Governmentality of Free Speech', (2016) 25 Social \& Legal Studies, 69; M.A. Nasir, 'Between the Metropole and the Postcolony', (2015), 34 Environment and Planning D: Society and Space, 1003; N. Rose, P. O'Malley and M. Valverde, 'Governmentality', (2006) 2 Annual Review of Law and Social Science, 83; M.A. Nasir, 'Biopolitics, Thanatopolitics and the Right to Life', (2017) 34 Theory, Culture, and Society, 75.
} 
conduct results in prioritising certain types of actions, and, more crucially, in discouraging others. In particular, the study here proposed shows how a governmental order closes itself to certain practices in order to reproduce itself.

\section{2 | THE CONSTITUTION OF FREEDOM: NEGATIVE GOVERNMENTALITY}

The law actively creates liberties, so it always causes-directly or indirectly-losses of liberty ... This raises the question of the correct distribution of liberties.

\section{Robert Alexy, A Theory of Constitutional Rights ${ }^{7}$}

Freedom requires both the positive affirmation of moral agency and the constraining of moral agency. There is no 'raw' or 'pure' understanding of freedom, and consequently, no 'raw' or 'pure' understanding of rights.

Praxis constitutes (and rationalises) autonomy. Rights are interwoven with collective goods, institutional structures, rationalities of government, and with law as a means of social integration. Not only the subjective rights of individuals enter into conflict, but also there are obvious tensions between the protection of the collective goods on which the effectiveness of the system of rights rests, and the protection of specific and concrete subjective rights. Furthermore, the very stability of a rights-based legal system can be undermined by the strategic use of rights. The holders of rights can make a purely tactical use of their rights with a view to undermining the foundations of the rights-based legal system and precipitate its demise. The stratagems through which Italian Fascists and German Nazis rose to power are illustrative in this regard. ${ }^{8}$ Consequently, the relationship between moral agency and rights cannot be conceived in value-neutral terms, at least not when it comes to the underlying principle of freedom. It is imperative that rights could not be used as the means to undermine democratic constitutionalism. ${ }^{9}$ To prevent that from happening, it is necessary to flesh out legal obligations, and to operationalise them through governmental practices, so that the holders of rights do not make use of their freedoms in ways that undermine freedom systematically. This negative side forms an integral part of full definition of rights and indeed should not be regarded as extraneous to rights. It is this full definition that makes a system out of a congeries of rights, and it is the full definition of rights that plays a major role in the shaping of the actual autonomous moral agents, and in defining the way they see the real and the legal worlds through both the rights and the limits to the rights that are said to prevail.

It follows from what has just been said that the full definition of rights has to include its 'negative side'. Not only what can be done with and through rights, but also what cannot be done with and through rights. This entails that a formal proclamation of rights is not enough. The 'morality of freedom', to use a Razian phrase, has to be fleshed out. Substantive and concrete choices are required when coming to terms with the limits and exceptions to rights. It is on the basis of such choices that legal rights are defined (and limited) and, consequently, freedoms defined (and limited). This results in subjects being required to perform certain actions and abstaining from others.

The resulting conception of rights is different (and, in my view, goes beyond) two influential conceptions of rights.

The first is that according to which rights are to be identified with a set of 'subjective' faculties. This is characteristic of the pre-political understanding of rights, which plays a major role not only in contractarian theories of

\footnotetext{
${ }^{7}$ R. Alexy, A Theory of Constitutional Rights (Oxford University Press, 2002), at 158 (original emphasis).

${ }^{8}$ Such a claim does not belittle at all the massive risk posed by actual public authorities breaching rights. The last century and the few years that have lapsed of the present one have been witness to massive rights violations by state actors, not infrequently justified in the name of various crises and emergencies.

${ }^{9}$ Schmitt notes in Legality and Legitimacy (Duke University Press, 2004): 'There is no middle road between the principled value neutrality of the functionalist system of legality and the principled value emphasis of the substantive constitutional guarantees ... Compared to a seriously intended value assertion and affirmation, conscientious value neutrality means a denial of values' (at 47).
} 
rights, but also in the conceptualisation of economic freedoms in the case law and secondary law of the EU. This understanding is reductionist because it misses the crucial point that actual freedom critically depends on legal standards and governmental practices. In fact, rights require for their effectiveness institutional discipline (and support). It is doubtful whether actual freedom exists outside the institutional context. The right to an autonomous life cannot be said to be guaranteed if people are placed at a major risk of living short and unhealthy lives, the prison system is in ruins, the economy fails, neighbouring states are belligerent, and children are not sent to schools by their parents. The idea of an autonomous life becomes meaningless without governmental discipline. The latter is a necessary condition for freedom to be both socially established and individually exercised in a satisfactory manner. Thus, limits and exceptions to rights are Janus-faced. On the one hand, such limits and exceptions restrain individual freedom and empower the state; at the same time, it is such limits and restrictions that render freedom possible and limit the power of public institutions by setting their legitimate scope. What emerges is the very principle of the rule of law, to the extent that the latter wards off not only arbitrary exercises of legal and political power, but also reproachable patterns of action and conduct from legal subjects. ${ }^{10}$ The former constitutes a necessary guarantee of freedom. The latter ensures the regulation of subjects through freedom. Both go hand in hand.

The second is the characterisation of rights as mere reflexes of objective law. Rights would have no autonomous substance or content, but would be merely a way of referring to the content of 'objective' law. By the same token, declarations of rights would have to be understood as just a reflex of the way power is organised in society. ${ }^{11}$ It goes without saying that such an understanding of rights has a rather sinister lineage. Still, such a conception tends to re-emerge with force when there is a founded or unfounded perception that the stability of the polity is being seriously threatened. The recent series of European crises fit into this pattern. The overlapping of financial, fiscal, economic and 'security' crisis in the EU, and very especially the Eurozone, have paved the way to specific policy proposals and general discourses that 'objectivise' rights. That does not make such an understanding more plausible.

Once we observe that the definition of rights has to comprise their 'negative' side, we are bound to observe that rights do not only determine standards of conduct (by means of producing normative knowledge) but they also play a major role in shaping and moulding the mentality of rights-holders, very especially on what concerns the 'negative' side of rights. Thus, limitation and exception clauses are part of 'negative' (inter)governmentality, which, among others, crucially cultivates a specific mentality of rights-holders that guarantees that freedom is exerted in ways that ensure the stability of the democratic constitutional order. It is banal to say that any legal system is premised on the expectation that legal norms will be complied with by their addressees. And still, law cannot produce by itself addressees that regard the legal system as legitimate (in fact, positive law cannot produce by itself the very reasons that ground its legitimacy). ${ }^{12}$ As a result, there is no guarantee that the legal constitution of freedom would result in compliance with the law on the side of those to whom it is addressed.

Democratic constitutional theory suggests that individuals should be both authors of (active agents) and subject to (targets and objects) the law. ${ }^{13}$ Autonomy and consent are coupled not through law itself, but through participatory

\footnotetext{
${ }^{10}$ Rule of law, Hayek notes, means 'that government in all its actions is bound by rules fixed and announced beforehand-rules which make it possible to foresee with fair certainty how authority will use its coercive power in given circumstances, and to plan one's individual affairs on the basis of this knowledge' (F. Hayek, The Road to Serfdom (first published 1944, Routledge 2001) at 75-76). Cf. J. Raz, 'The Rule of Law and its Virtue', (1997) 93 Law Quarterly Review, 195. In Sunday Times v. the United Kingdom, App. no. 6538/74 (ECtHR, 26 April 1979), http://hudoc.echr.coe.int/eng\#\{\%22appno\%22:[\%226538/74\%22],\%22itemid\%22:[\%22001-57583\%22]\}, the ECtHR noted: 'A norm cannot be regarded as a "law" unless it is formulated with sufficient precision to enable the citizen to regulate his conduct' (\$49).

${ }^{11}$ Such a trend is reflected, most notably, in a few of the major writings of Carl Schmitt, Lorenz von Stein and Sergio Panunzio.

12 J. Habermas, Between Facts and Norms: Contributions to a Discourse Theory of Law and Democracy (Cambridge University Press, 1996), at 358-359. Post calls this the 'paradox of public discourse', that the law may not be used to enforce the civility rules that make rational deliberation possible (R. Post, Constitutional Domains (Harvard University Press, 1995), at 146-147).
}

${ }^{13}$ E.g., Habermas, above, n. 12, at 113-123. 
and civic structures which foster living conditions in which individuals are safe, schooled and healthy, integrated into economic structures based on reciprocity, and so on and so forth. ${ }^{14}$ General reasonability is tied to universal acceptability. ${ }^{15}$ The law cannot establish the very conditions of its own legitimacy. By the same token, subjects to the law may undermine the stability of the law by means of a strategic abuse of their rights. It would then be mistaken to reconstruct expressions of choice and opinion, coming hand in hand with the subversion of law through law, as exercises of self-legislation, popular sovereignty, and consent and its legitimacy. Limitations and restrictions undermining the abuse of agency are required. In such circumstances, and only in such circumstances, actions and governmental practices are required to uphold the rights-based legal system. ${ }^{16}$ Consequently, those societies that constitutionalise human rights but lack practices addressing conduct that human rights structurally presuppose (e.g., political transparency, independence of judiciary, professional civil service, strong economy), i.e., practices that rationalise what autonomous life is and what not, remain unable to either guarantee human rights effectively or to shield rights-based norms from the possibility of systemic threats. ${ }^{17}$

Negative governmentality builds a bridge between the form of the legal system and the substantive content of the norms that are part of it. A purely formal understanding, for example, of procedural standards ignores the extent to which they remain substantively nested with constitutional principles. Thus, constitutional principles define procedural standards in contextual (e.g., forms of behaviour that procedure considers relevant), normative (e.g., presupposition of rational will-formation), and systemic (e.g., the role and scope of procedural standards in certain key political institutions) terms. In other words, the formal aspect of democratic procedures interrelates with the legal rules that determine the shape of the legal system, i.e., democratic constitutional system. In the same vein, formal, procedural analysis of law is always insufficient, because it does not take into account the fundamental importance of the tension between form and substance, or what is the same, the eventuality that formal compliance may result in substantive infringement. Means and ends are necessarily interconnected in law-making and law adjudication and implementation. The outcome of a procedure is to be regarded as legitimate if, and only if, the outcome is in line with the normative conditions that render the procedure legitimate. Consequently, groups or political parties cannot legitimise their anticonstitutional activities either by participating in the procedure or by complying with procedural standards only in a

\footnotetext{
${ }^{14}$ In order to supplement legal rules with an apt political character of a society, Kelsen notes that 'in practice, civic education is one of the principle demands' of the democratic constitutional order. He further notes: 'All education, it is true, is based on the relationship between teacher and student-an intellectual form of the leader-follower relation-and therefore (in a good sense) essentially authoritarian in character. Nevertheless, the problem of democracy presents itself in social practice as an educational problem on the grandest scale' (The Essence and Value of Democracy (Rowman \& Littlefield, 1929), at 95). In a similar vein, Rorty notes: 'Producing generations of nice, tolerant, well-off, secure, other-respecting students in all parts of the world is just what is needed-indeed, all that is needed-to achieve an Enlightenment utopia. The more youngsters like this we can raise, the stronger and more global our human rights culture will become', The Rorty Reader (Wiley, 2010), at 361.

${ }^{15}$ Reasonability requires that the rational conditions that establish a free order allow deliberation and choice to an extent that those conditions are not effectively jeopardised. Normatively, deliberation occurs within such an order, not about ending it. If this gap between reasonability and rationality is not bridged, one faces a paradox. A famous remark in this regard is Rousseau's: 'In order for a nascent people to appreciate sound political maxims and follow the fundamental rules of statecraft, the effect would have to become the cause; the social spirit, which should be the product of the way in which the country was founded would have to preside over the founding itself; and, before the creation of the laws, men would have to be what they should become by means of those same laws' (The Social Contract at II: ch. 7).

${ }^{16}$ Raz notes: 'Since individuals are guaranteed adequate rights of political participation in the liberal state and since such a state is guided by a public morality expressing concern for individual autonomy, its coercive measures do not express an insult to the autonomy of individuals. It is common knowledge that they are motivated not by lack of respect for individual autonomy but by concern for it. After all, coercion can be genuinely for the good of the coerced and can even be sought by them', The Morality of Freedom (Oxford University Press, 1986), at 156-7.

${ }^{17}$ The question how a rights-based legal system is to be established cannot be answered exhaustively by referring reflexively to human rights law. The rationale of negative governmentality closes the legal gap between norms and their implementation. In fact, the effectiveness of human rights depends to the extent that a society interrelates human rights norms with practices prioritising certain conduct, and discouraging certain others. Consequently, at moments when a rights-based legal system is being established, standards like Article 15, for example, could be retroactively used to justify such legal and political transitions. Once installed, however, such a legal system can then be used ex post facto to deal with the violations of specific human rights during and prior to such transitions.
} 
formal sense. To the extent that the democratic procedures themselves do not affirm something concrete and remain rather formal, legal rules underlie their formal basis by delimiting acceptable forms of discursive contributions and by restricting certain unreasonable inputs and outputs, i.e., by specifying what these procedures are not, what kind of behaviour remains unacceptable, and what kind of uses participants cannot put them to. ${ }^{18}$

In sum, under the heading of 'negatively governmentality', primarily three related things, within a legal system, can be analysed.

First, it is shaping freedom. This extends to identifying what cannot be done through freedom. Such constriction helps shape autonomy and its agents.

Second, it is analysing abuse of freedom. This requires focusing on the essence of (un)freedom. It entails studying the function of those rationalities that identify subversive conduct, practices that manage it, standards that elaborate the befitting way to deal with them, and strategies that bring an abusive subject back within the legal context.

Third, it is legally regulating abuse. This relates the problem of preserving a legal system back to the legal rules. Thus, negative governmentality extends to the question of developing practices of government whose task is to ensure that free subjects do not govern themselves in an abusive manner. It is the social task of those legal structures that seek to uphold a culture of autonomy to determine in what manner can freedoms be, in Alexy's words, 'correctly distributed' for subjects spread over a range of socio-political formations.

\section{3 | LIMITATION AND 'EXCEPTION' CLAUSES}

Autonomy is only possible in a framework of constraints.

Joseph Raz, The Morality of Freedom ${ }^{19}$

\subsection{The structural role of limitation and exception clauses}

Limitation and exception clauses qualify and calibrate ECHR rights by setting them in their wider social, economic and political context. They perform three main functions. Firstly, these clauses open rights up to various notions of the collective good (including economic well-being, territorial integrity, health and safety, the maintenance of law and order), preventing that 'law [refers] only to law'.20 Secondly, it is through limitation and exception clauses that the guarantee of rights is related to the specific and concrete governmental practices intended to shape the conduct of legal subjects. Thirdly, limitation clauses and exceptions reconcile social change (leading to different understandings of what the collective good entails) with legal determination. In particular, the interplay between abstract rights and

\footnotetext{
${ }^{18}$ With an awareness that certain 'unreasonable' doctrines may find it impossible 'to abide by constitutional regime except as a modus vivendi' (at 489), Rawls believes that it is important that a free society develop legal standards that do not consider inputs from these doctrines as equally legitimate in the overall legitimation pool in Political Liberalism (Columbia University Press, 2005). He notes: '[The] existence [of unreasonable doctrines] sets a limit to the aim of fully realizing a reasonable democratic society with its ideal of public reason and the idea of legitimate law. This fact is not a defect or failure of the idea of public reason, but rather it indicates that there are limits to what public reason can accomplish' (at 489). Further: 'That there are [unreasonable] doctrines that reject one or more democratic freedom is itself a permanent fact of life, or seems so. This gives us the practical task of containing them-like war and disease-so that they do not overturn political justice' (at 64). Thus, although future generations, from a legal perspective, do not hold any right because they are inexistent (and, consequently cannot have their legal rights violated or, even for that matter, have them protected by a court), the legal standards shaping, restricting and conditioning the freedoms of existing rights-holders (i.e., negative governmentality) ensure that future generations inherit a legal system that would treat them as rights-holders. Cf. J. Rawls, Justice as Fairness (Harvard University Press, 2001), at 159).

${ }^{19}$ Raz, above, n. 16, at 155.

${ }^{20}$ Antonin Schütz, 'L'immaculée conception de l'interpète et l'émergence du système juridique: A propos de fictionet construction en droit', (1995) 21 Droits, 120, cited in G. Agamben, State of Exception (University of Chicago Press, 2005), at 26.
} 
context renders possible a stable, and still open to change, interpretative framework of constitutional standards, in this case, ECHR standards. ${ }^{21}$

\subsection{Limitation clauses}

2. The exercise of these freedoms, since it carries with it duties and responsibilities, may be subject to such formalities, conditions, restrictions or penalties as are prescribed by law and are necessary in a democratic society, in the interests of national security, territorial integrity or public safety, for the prevention of disorder or crime, for the protection of health or morals, for the protection of the reputation or rights of others, for preventing the disclosure of information received in confidence, or for maintaining the authority and impartiality of the judiciary.

Article 10(2) ECHR, Right to freedom of expression

Limitation clauses (Table 1) are a defining element of the right being limited. This does not entail that they are an 'inherent' part of the right, ${ }^{22}$ but rather have a relevance of their own, as clauses which identify the protective reach of each right by reference to the values and objectives that underpin it. To put it differently, by setting the rightful scope within which a right can be limited, limitation clauses specify the substantive content and the purpose of the limiting act. $^{23}$ Resultantly, the conduct of the addressees of the law is regulated in view of the objectives underpinning the limitation clauses, at the very same time that the limited right is afforded legal protection. This is reflected in the fact that when constructing the limitation clauses, the ECtHR has engaged in analysing the justifiability of the specific interferences which presupposes (at least to a relevant extent) the legitimacy of the interferences. To illustrate the point: When the ECtHR finds that activities that cause noise (within certain limits) are justified, despite limiting the right to respect for private life (including privacy of the home), ${ }^{24}$ the Court is affirming that a wide understanding of economic well-being determines (and defines) the concrete rights enjoyed by the plaintiffs.

What has just been said entails that it is the limitation of rights that defines what it means to live in a society that assigns a central value to autonomy. If we consider the case law of the ECtHR systematically, we will conclude that an autonomous life is defined, for example, as the life of individuals who are members of a territorially secure state, in which they enjoy participation in a performing economy with low levels of unemployment, and in which they enjoy access to education and health. The very fact that I am acknowledged rights entails that I can challenge the concrete interpretation of the rights I enjoy, including the limits to those rights. What I cannot challenge is the existence, rationale and function of limits to rights. In other words, while the specific configuration of the limits and exceptions to rights can be challenged, the constitutive role of limitations cannot be challenged. As was pointed above, but is perhaps worth repeating now, limitation clauses and limiting practices have a constitutive character and effect which lies at the core of not only individual autonomy but also of an autonomous society. ${ }^{25}$ At the same time, however, it is of

\footnotetext{
${ }^{21}$ In Soering v. the United Kingdom, App. no. 14038/88 (ECtHR, 7 July 1989), http://hudoc.echr.coe.int/eng\#\{\%22appno\%22: [\%2214038/88\%22],\%22itemid\%22:[\%22001-57619\%22]\}, the ECtHR noted that 'the object and purpose of the Convention as an instrument for the protection of individual human beings require that its provisions be interpreted and applied so as to make its safeguards practical and effective' (\$87).

${ }^{22}$ Golder v. the UK, App. no. 4451/70 (ECtHR, 21 February 1975), http://hudoc.echr.coe.int/eng\#\{\%22appno\%22:[\%224451/ 70\%22],\%22itemid\%22:[\%22001-57496\%22]\}, §21, 40.

${ }^{23}$ Thus, the test performed by the ECtHR in its case law of discerning whether rights have been interfered with in a proportionate pursuance of 'legitimate aims' is crucial. It in turn makes the interfering measure legitimate, shifting this concept of judicial interpretation, as an effect, from focusing on ends to the determination of proper means.

${ }^{24}$ See, Powell and Rayner v. the UK, App. no. 9310/81 (ECtHR, 21 February 1990), http://hudoc.echr.coe.int/eng\#\{\%22appno\%22: [\%229310/81\%22],\%22itemid\%22:[\%22001-57622\%22]\}, §37-45, and Hatton and Others v. the UK, App. no. $36022 / 97$ (ECtHR, 8 July 2003), http://hudoc.echr.coe.int/eng\#\{\%22appno\%22:[\%2236022/97\%22],\%22itemid\%22:[\%22001-61188\%22]\}, §116-130.

${ }^{25}$ 'Constitutional rights can only be limited by or on the basis of norms likewise with constitutional status', Alexy, above, n. 7, at 185.
} 
TABLE 1 Limitation clauses: Articles 8-11

\begin{tabular}{|c|c|c|c|c|}
\hline ECHR Articles & $\begin{array}{l}\text { Article } 8 \text { ECHR. Right to } \\
\text { Respect for private and } \\
\text { family life }\end{array}$ & $\begin{array}{l}\text { Article } 9 \mathrm{ECHR} \text {. } \\
\text { Freedom of thought, } \\
\text { conscience, and } \\
\text { religion }\end{array}$ & $\begin{array}{l}\text { Article } 10 \text { ECHR. } \\
\text { Freedom of expression }\end{array}$ & $\begin{array}{l}\text { Article } 11 \text { ECHR. } \\
\text { Freedom of } \\
\text { assembly and } \\
\text { association }\end{array}$ \\
\hline $\begin{array}{l}\text { Paragraphs that } \\
\text { mention } \\
\text { limitations to } \\
\text { the rights that } \\
\text { their } \\
\text { corresponding } \\
\text { article protects }\end{array}$ & $\begin{array}{l}\text { Article } 8(2) \text { ECHR. There } \\
\text { shall be no } \\
\text { interference by a } \\
\text { public authority with } \\
\text { the exercise of this } \\
\text { right except such as is: }\end{array}$ & $\begin{array}{l}\text { Article 9(2) ECHR. } \\
\text { Freedom to manifest } \\
\text { one's religion or } \\
\text { beliefs shall be } \\
\text { subject only to such } \\
\text { limitations as are: }\end{array}$ & $\begin{array}{l}\text { Article } 10(2) \text { ECHR. The } \\
\text { exercise of these } \\
\text { freedoms, since it } \\
\text { carries with it duties } \\
\text { and responsibilities, } \\
\text { may be subject to such } \\
\text { formalities, conditions, } \\
\text { restrictions or penalties } \\
\text { as are: }\end{array}$ & $\begin{array}{l}\text { Article } 11(2) E C H R . \\
\text { No restrictions } \\
\text { shall be placed on } \\
\text { the exercise of } \\
\text { these rights other } \\
\text { than such as are: }\end{array}$ \\
\hline $\begin{array}{l}\text { Compliance with } \\
\text { the law (with } \\
\text { respect to both } \\
\text { its form and its } \\
\text { quality) }\end{array}$ & in accordance with law & prescribed by law & prescribed by law & prescribed by law \\
\hline $\begin{array}{l}\text { Democratic } \\
\text { necessity } \\
\text { (procedural and } \\
\text { substantive) }\end{array}$ & $\begin{array}{l}\text { and is necessary in a } \\
\text { democratic society }\end{array}$ & $\begin{array}{c}\text { and are necessary in a } \\
\text { democratic society }\end{array}$ & $\begin{array}{l}\text { and are necessary in a } \\
\text { democratic society, }\end{array}$ & $\begin{array}{l}\text { and are necessary in } \\
\text { a democratic } \\
\text { society }\end{array}$ \\
\hline $\begin{array}{l}\text { Political } \\
\text { necessities } \\
\text { relating to } \\
\text { national } \\
\text { security }\end{array}$ & $\begin{array}{l}\text { in the interests of } \\
\text { national security, }\end{array}$ & & $\begin{array}{l}\text { in the interests of national } \\
\text { security, }\end{array}$ & $\begin{array}{l}\text { in the interests of } \\
\text { national security }\end{array}$ \\
\hline $\begin{array}{l}\text { Political } \\
\text { necessities } \\
\text { relating to } \\
\text { territorial } \\
\text { safety }\end{array}$ & & & territorial integrity & \\
\hline Social concerns & public safety & $\begin{array}{l}\text { in the interests of } \\
\text { public safety, }\end{array}$ & or public safety, & or public safety, \\
\hline $\begin{array}{l}\text { Economic } \\
\text { necessities }\end{array}$ & $\begin{array}{l}\text { or the economic well- } \\
\text { being country, }\end{array}$ & & & \\
\hline $\begin{array}{l}\text { Maintenance of } \\
\text { law and order }\end{array}$ & $\begin{array}{c}\text { for the prevention of } \\
\text { disorder or crime, }\end{array}$ & $\begin{array}{l}\text { for the protection of } \\
\text { public order, }\end{array}$ & $\begin{array}{c}\text { for the prevention of } \\
\text { disorder or crime, }\end{array}$ & $\begin{array}{l}\text { for the prevention of } \\
\text { disorder or crime, }\end{array}$ \\
\hline $\begin{array}{l}\text { Public health, } \\
\text { general } \\
\text { welfare, social } \\
\text { policy }\end{array}$ & $\begin{array}{l}\text { for the protection of } \\
\text { health or morals, }\end{array}$ & health or morals, & $\begin{array}{c}\text { for the protection of } \\
\text { health or morals, }\end{array}$ & $\begin{array}{l}\text { for the protection of } \\
\text { health or morals }\end{array}$ \\
\hline $\begin{array}{l}\text { Consideration of } \\
\text { rights and } \\
\text { freedoms of } \\
\text { others }\end{array}$ & $\begin{array}{l}\text { or for the protection of } \\
\text { the rights and } \\
\text { freedoms of others. }\end{array}$ & $\begin{array}{l}\text { or for the protection of } \\
\text { the rights and } \\
\text { freedoms of others. }\end{array}$ & $\begin{array}{l}\text { for the protection of the } \\
\text { reputation or rights of } \\
\text { others, }\end{array}$ & $\begin{array}{l}\text { or for the protection } \\
\text { of the rights and } \\
\text { freedoms of } \\
\text { others. }\end{array}$ \\
\hline $\begin{array}{l}\text { Protecting } \\
\text { confidentiality } \\
\text { within certain } \\
\text { social, } \\
\text { economic, and } \\
\text { political } \\
\text { institutions }\end{array}$ & & & $\begin{array}{l}\text { for preventing the } \\
\text { disclosure of } \\
\text { information received in } \\
\text { confidence, }\end{array}$ & \\
\hline $\begin{array}{l}\text { Preserving the } \\
\text { independence } \\
\text { and objectivity } \\
\text { of judicial } \\
\text { bodies }\end{array}$ & & & $\begin{array}{l}\text { or for maintaining the } \\
\text { authority and } \\
\text { impartiality of the } \\
\text { judiciary. }\end{array}$ & \\
\hline
\end{tabular}


vital importance that governmental practices that limit rights are determined and constrained by the very rights they limit, instead of becoming ends in themselves. To illustrate the point: There may well be very good reasons why the right of privacy of a specific person or persons has to be limited and restricted. If there were good grounds to conclude that a certain $\mathrm{Mr} \mathrm{X}$ is engaged in a criminal conspiracy to undermine national security, a judge would be justified in ordering the eavesdropping of the communications of $\mathrm{Mr} \mathrm{X}^{26}$ Still, a potential abuse of that state power has to be prevented through procedural safeguards, including judicial supervision.

\subsection{Exception clauses}

The ECHR articles also contain certain exceptions. I hereafter refer to them as exception clauses (Table 2). For example, the guarantee of the right to life finds its exception when 'quelling a riot or insurrection' (Article 2(2c) ECHR).

Broadly speaking, exception clauses perform two related functions. Firstly, exception clauses make certain rights claims inapplicable within certain domains. For example, Article 4 prohibits forced labour, but the companion exception clause makes clear that it is not possible to characterise compulsory military recruitment during wartime as forced labour (Article 4(3b) ECHR).

Secondly, exception clauses make a specific construction of that right (by reference to specific conditions or historical context) part of the normative understanding of the right. For example, Article 5 on the right to liberty and security applies in a different manner to mentally ill or individuals suffering from infectious diseases. Thus, mentally ill, alcoholics or individuals suffering from infectious diseases are not primarily detained with a view to bringing them 'before the competent legal authorities'-which is crucially mentioned in Articles 5(1a-1d) and 5(3) ECHR. Albeit it presupposes judicial supervision, those that Article 5 ECHR mentions in exceptional terms can be justifiably detained without a prior court order. ${ }^{27}$ Similarly, albeit those that are mentioned in exceptional terms remain rights-holders and can make Article 5 claims, praxis constitutionalising and rationalising autonomy enables law to interpret their rights in a contextual, and hence in an exceptional, manner. Simply put, unlike a convicted murderer, I, as a mentally unstable individual, am detained not for what I have done but for what I am, and thus I am detained primarily for my own therapy and welfare. By the same token, the fact that Article 3 does not foresee exceptions does not entail that the training of special operation soldiers be abolished because it is inhuman or degrading; doing so would imply constructing the right in a manner blind to the specific historical and protective context in which it makes sense. ${ }^{28}$ To put it differently, exception clauses exempt certain institutional setups, practices and rationalities from the breadth of the rights, in order to make sense of the way those very rights are to be actualised in society.

\footnotetext{
${ }^{26}$ See, e.g., Leander v. Sweden, App. no. 9248/81 (ECtHR, 26 March 1987), http://hudoc.echr.coe.int/eng\#\{\%22appno\%22:[\%229248/ 81\%22],\%22itemid\%22:[\%22001-57519\%22]\}, §62; Huvig v. France, App. no. 11105/84 (ECtHR, 24 April 1990), http://hudoc.echr. coe.int/eng\#\{\%22appno\%22:[\%2211105/84\%22],\%22itemid\%22:[\%22001-57627\%22]\}, §33; Malone v. the UK, App. no. 8691/79 (ECtHR, 26 April 1985), http://hudoc.echr.coe.int/eng\#\{\%22appno\%22:[\%228691/79\%22],\%22itemid\%22:[\%22001-57532\%22]\}, $\S 79,87$.

${ }^{27}$ See, e.g., Winterwerp v. the Netherlands, App. no. 6301/73 (ECtHR, 24 October 1979), http://hudoc.echr.coe.int/eng\#\{\%22appno\% 22:[\%226301/73\%22],\%22itemid\%22:[\%22001-57597\%22]\}, §38; Aerts v. Belgium, App. no. 25357/94 (ECtHR, 30 July 1998), http:// hudoc.echr.coe.int/eng\#\{\%22fulltext\%22:[\%2225357/94\%22],\%22itemid\%22:[\%22001-58209\%22]\}, §46; Johnson v. the UK, App. no. 22520/93 (ECtHR, 24 October 1997), http://hudoc.echr.coe.int/eng\#\{“fulltext”:[“22520/93"],"itemid":[“001-58110"]\}, §61-66; Koniarska v. the UK, App. no. 33670/96 (ECtHR, 12 October 2000), http://hudoc.echr.coe.int/eng\#\{\%22fulltext\%22: [\%22\\%2233670/96\\%22\%22],\%22itemid\%22:[\%22001-5480\%22]\}, The Law.

${ }^{28}$ In her study of the structure of war in the twentieth century, historian Joanna Burke notes: 'In all military training programs, the fundamental process was the same: individuals had to be broken down to be rebuilt into efficient fighting men. The basic tenets included depersonalisation, uniforms, lack of privacy, forced social relationships, tight schedules, lack of sleep, disorientation followed by rites of reorganisation according to military codes, arbitrary rules, and strict punishment. These methods of brutalisation were similar to those carried out in regimes where men were taught to torture prisoners: the difference resided in the degree of violence involved, not its nature' (An Intimate History of Killing: Face-to-Face Killing in Twentieth-Century Warfare (Basic Books, 1999), at 67).
} 
TABLE 2 Exception clauses: Articles 2, 4, 5, and (to an extent) ${ }^{29} 6$ and 11

\begin{tabular}{|c|c|c|c|c|c|}
\hline ECHR Articles & $\begin{array}{l}\text { Article } 2 \text { ECHR. } \\
\text { Right to life }\end{array}$ & $\begin{array}{l}\text { Article } 4 \text { ECHR. } \\
\text { Prohibition of } \\
\text { slavery and forced } \\
\text { labour }\end{array}$ & $\begin{array}{l}\text { Article } 5 \text { ECHR. } \\
\text { Right to liberty } \\
\text { and security }\end{array}$ & $\begin{array}{l}\text { Article } 6 \text { ECHR. } \\
\text { Right to a fair trial }\end{array}$ & $\begin{array}{l}\text { Article } 11 \text { ECHR. } \\
\text { Freedom of } \\
\text { assembly and } \\
\text { association }\end{array}$ \\
\hline $\begin{array}{l}\text { Paragraphs that } \\
\text { mention } \\
\text { exceptions to } \\
\text { the rights that } \\
\text { their } \\
\text { corresponding } \\
\text { article protects }\end{array}$ & $\begin{array}{l}\text { Article 2(2) ECHR. } \\
\text { Deprivation of } \\
\text { life shall not be } \\
\text { regarded as } \\
\text { inflicted in } \\
\text { contravention of } \\
\text { this Article when } \\
\text { it results from } \\
\text { the use of force } \\
\text { which is no } \\
\text { more than } \\
\text { absolutely } \\
\text { necessary: }\end{array}$ & $\begin{array}{l}\text { Article } 4(3) \text { ECHR. } \\
\text { For the purpose } \\
\text { of this article the } \\
\text { term 'forced or } \\
\text { compulsory } \\
\text { labour' shall not } \\
\text { include: }\end{array}$ & $\begin{array}{l}\text { Article 5(1) ECHR. } \\
\text { Everyone has } \\
\text { the right to } \\
\text { liberty and } \\
\text { security of } \\
\text { person. No one } \\
\text { shall be deprived } \\
\text { of his liberty } \\
\text { save in the } \\
\text { following cases } \\
\text { and in } \\
\text { accordance with } \\
\text { a procedure } \\
\text { prescribed by } \\
\text { law: }\end{array}$ & $\begin{array}{l}\text { Article 6(1) } \\
\text { ECHR. }^{30} \text { In the } \\
\text { determination of } \\
\text { his civil rights } \\
\text { and obligations } \\
\text { or of any } \\
\text { criminal charge } \\
\text { against him, } \\
\text { everyone is } \\
\text { entitled to a fair } \\
\text { and public } \\
\text { hearing ... } \\
\text { judgment shall } \\
\text { be pronounced } \\
\text { publicly but the } \\
\text { press and public } \\
\text { may be excluded } \\
\text { from all or part } \\
\text { of the trial: }\end{array}$ & $\begin{array}{l}\text { Article 11(2). This } \\
\text { article shall not } \\
\text { prevent the } \\
\text { imposition of } \\
\text { lawful } \\
\text { restrictions on } \\
\text { the exercise of } \\
\text { these rights by } \\
\text { members: }\end{array}$ \\
\hline
\end{tabular}

\begin{tabular}{|c|c|}
\hline $\begin{array}{l}\text { Pre-empting or } \\
\text { countering } \\
\text { that violence } \\
\text { which is } \\
\text { unlawful }\end{array}$ & $\begin{array}{l}\text { (2a) in defence of } \\
\text { any person from } \\
\text { unlawful } \\
\text { violence; }\end{array}$ \\
\hline $\begin{array}{l}\text { Necessity of } \\
\text { lawful } \\
\text { detention and } \\
\text { legitimacy of } \\
\text { prison as an } \\
\text { institution }\end{array}$ & $\begin{array}{l}\text { (2b) in order to } \\
\text { effect a lawful } \\
\text { arrest or to } \\
\text { prevent the } \\
\text { escape of a } \\
\text { person lawfully } \\
\text { detained: }\end{array}$ \\
\hline
\end{tabular}

(3a) any work required to be done in the ordinary course of detention imposed according to the provisions of Article 5 of this Convention or during conditional release from such detention; (1a) the lawful detention of a person after conviction by a competent court;

(1b) the lawful arrest or detention of a person for noncompliance with the lawful order of a court or in order to secure the fulfilment of any obligation prescribed by law;

(1c) the lawful arrest or detention of a person effected for the purpose of bringing him before the competent legal authority on reasonable suspicion of having committed an offence or when it is reasonably considered 
TABLE 2 (Continued)

\begin{tabular}{|c|c|c|c|c|c|}
\hline ECHR Articles & $\begin{array}{l}\text { Article } 2 \text { ECHR. } \\
\text { Right to life }\end{array}$ & $\begin{array}{l}\text { Article } 4 \text { ECHR. } \\
\text { Prohibition of } \\
\text { slavery and forced } \\
\text { labour }\end{array}$ & $\begin{array}{l}\text { Article } 5 \text { ECHR. } \\
\text { Right to liberty } \\
\text { and security }\end{array}$ & $\begin{array}{l}\text { Article } 6 \text { ECHR. } \\
\text { Right to a fair trial }\end{array}$ & $\begin{array}{l}\text { Article } 11 \text { ECHR. } \\
\text { Freedom of } \\
\text { assembly and } \\
\text { association }\end{array}$ \\
\hline & & & $\begin{array}{l}\text { necessary to } \\
\text { prevent his } \\
\text { committing an } \\
\text { offence or } \\
\text { fleeing after } \\
\text { having done so; }\end{array}$ & & \\
\hline $\begin{array}{l}\text { Defence related } \\
\text { necessities and } \\
\text { the legitimacy } \\
\text { of military as } \\
\text { an institution }\end{array}$ & & $\begin{array}{l}\text { (3b) any service of } \\
\text { a military } \\
\text { character or, in } \\
\text { case of } \\
\text { conscientious } \\
\text { objectors in } \\
\text { countries where } \\
\text { they are } \\
\text { recognised, } \\
\text { service exacted } \\
\text { instead of } \\
\text { compulsory } \\
\text { military service; }\end{array}$ & & & $\begin{array}{l}\text { of the armed } \\
\text { forces, }\end{array}$ \\
\hline $\begin{array}{l}\text { Countering } \\
\text { threats to } \\
\text { public order } \\
\text { and collective } \\
\text { well-being }\end{array}$ & $\begin{array}{l}\text { (2c) in action } \\
\text { lawfully taken } \\
\text { for the purpose } \\
\text { of quelling a riot } \\
\text { or insurrection. }\end{array}$ & $\begin{array}{l}\text { (3c) any service } \\
\text { exacted in case } \\
\text { of an emergency } \\
\text { or calamity } \\
\text { threatening the } \\
\text { life or well-being } \\
\text { of the } \\
\text { community; }\end{array}$ & & $\begin{array}{l}\text { in the interest of } \\
\text { public order or } \\
\text { national security } \\
\text { in a democratic } \\
\text { society, of } \\
\text { morals }\end{array}$ & \\
\hline $\begin{array}{l}\text { Law and order } \\
\text { related } \\
\text { necessities and } \\
\text { the legitimacy } \\
\text { of police as an } \\
\text { institution }\end{array}$ & & & & & $\begin{array}{l}\text { of the police or } \\
\text { of the } \\
\text { administration } \\
\text { of the State. }\end{array}$ \\
\hline Civic obligations & & $\begin{array}{l}\text { (3d) any work or } \\
\text { service which } \\
\text { forms part of } \\
\text { normal civic } \\
\text { obligations. }\end{array}$ & & & \\
\hline $\begin{array}{l}\text { Considerations of } \\
\text { the welfare of } \\
\text { children, and } \\
\text { the legitimacy } \\
\text { of } \\
\text { corresponding } \\
\text { institutions } \\
\text { (i.e., schools, } \\
\text { care } \\
\text { institutions, } \\
\text { juvenile } \\
\text { centres) }\end{array}$ & & & $\begin{array}{l}\text { (1d) the detention } \\
\text { of a minor by } \\
\text { lawful order for } \\
\text { the purpose of } \\
\text { educational } \\
\text { supervision or } \\
\text { his lawful } \\
\text { detention for } \\
\text { the purpose of } \\
\text { bringing him } \\
\text { before the } \\
\text { competent legal } \\
\text { authority; }\end{array}$ & $\begin{array}{l}\text { where the } \\
\text { interests of } \\
\text { juveniles ... } \\
\text { so require }\end{array}$ & \\
\hline $\begin{array}{l}\text { Health-related } \\
\text { considerations, } \\
\text { and the } \\
\text { legitimacy of } \\
\text { corresponding }\end{array}$ & & & $\begin{array}{l}\text { (1e) the lawful } \\
\text { detention of } \\
\text { persons for the } \\
\text { prevention of } \\
\text { the spreading of }\end{array}$ & & \\
\hline
\end{tabular}


TABLE 2 (Continued)

\begin{tabular}{|c|c|c|c|c|c|}
\hline ECHR Articles & $\begin{array}{l}\text { Article } 2 \text { ECHR. } \\
\text { Right to life }\end{array}$ & $\begin{array}{l}\text { Article } 4 \text { ECHR. } \\
\text { Prohibition of } \\
\text { slavery and forced } \\
\text { labour }\end{array}$ & $\begin{array}{l}\text { Article } 5 \text { ECHR. } \\
\text { Right to liberty } \\
\text { and security }\end{array}$ & $\begin{array}{l}\text { Article } 6 \text { ECHR. } \\
\text { Right to a fair trial }\end{array}$ & $\begin{array}{l}\text { Article } 11 \text { ECHR. } \\
\text { Freedom of } \\
\text { assembly and } \\
\text { association }\end{array}$ \\
\hline $\begin{array}{l}\text { institutions } \\
\text { (i.e., hospitals, } \\
\text { asylums, } \\
\text { rehabilitation } \\
\text { centres, } \\
\text { detention } \\
\text { wards) }\end{array}$ & & & $\begin{array}{l}\text { infectious } \\
\text { diseases, of } \\
\text { persons of } \\
\text { unsound mind, } \\
\text { alcoholics or } \\
\text { drug addicts or } \\
\text { vagrants; }\end{array}$ & & \\
\hline $\begin{array}{l}\text { Political necessity } \\
\text { relating to } \\
\text { state's } \\
\text { management } \\
\text { of entry into } \\
\text { and exit from } \\
\text { their territories }\end{array}$ & & & $\begin{array}{l}\text { (1f) the lawful } \\
\text { arrest or } \\
\text { detention of a } \\
\text { person to } \\
\text { prevent his } \\
\text { effecting an } \\
\text { unauthorised } \\
\text { entry into the } \\
\text { country or of a } \\
\text { person against } \\
\text { whom action is } \\
\text { being taken with } \\
\text { a view to } \\
\text { deportation or } \\
\text { extradition. }\end{array}$ & & \\
\hline $\begin{array}{l}\text { Other } \\
\text { unforeseen, } \\
\text { special } \\
\text { circumstances }\end{array}$ & & & & $\begin{array}{l}\text { or to the extent } \\
\text { strictly } \\
\text { necessary in the } \\
\text { opinion of the } \\
\text { court in special } \\
\text { circumstances } \\
\text { where publicity } \\
\text { would prejudice } \\
\text { the interests of } \\
\text { justice. }\end{array}$ & \\
\hline
\end{tabular}

${ }^{29}$ Both Articles 6 and 11 simultaneously exhibit the tendencies of appreciating certain exceptions and determining certain limitations. Whereas Article 11(2) mentions 'restrictions', it ends by mentioning an important exception. Similarly, whereas Article 6(1) 'excludes' certain parties from 'all or part of the trial', its opening clause limits complaints to civil and criminal cases (rather than complaints relating to administrative measures, for example). Moreover, the interpretation of Article 6 by the Convention organs has made room for certain 'limitations by implication' on the rights it protects (Golder, above, n. 22, §38) that, even when not mentioned in the text of the article, are necessary in order to place this article in its proper context (cf. Stanev v. Bulgaria, App. no. 36760/06 (ECtHR, 17 January 2012), http://hudoc.echr.coe.int/eng\#\{\%22itemid\%22:[\%22001-108690\%22]\}, §230). Thus, the case law of Article 6 ECHR talks about equality of arms, proportionality between means employed by the public authorities and the legitimate aims they wanted to achieve, balance between time given to defence and the overall time of the trial, among others. However, to the extent that the text of Article 6 does not mention limitations, and the case law does not analyse the applicability of the right first and then reconstruct proper limitations systematically, it appears conceptually mistaken to list Article 6 with those articles that explicitly contain limitation clauses. Nevertheless, attention must be paid to the overall context in which the Convention organs interpret Article 6 as an important non-derogable right and the way they consider how the imposition of limitations on this right by public authorities remains compatible with guarantee of an effective and fair trial.

${ }^{30}$ Article 6(1) only deals with the aspect of 'publicness' in the context of trial and judgment. This does not function as a limitation clause, despite delimiting the breadth of 'publicness'. Article 6(1) simply 'excludes press and public' in certain situations from 'all or part of the trial'; it does not seek to balance various aspects. In other words, albeit the exceptions relating to publicness mentioned in Article 6(1) chime with limitations mentioned in Articles 8-11 (i.e., public order, national security, in the interests of society or of morals), Article 6(1)'s keyword refers to exclusion (i.e., 'excluded') rather than 'interferences' (Article 8(2)), 'limitations' (Article 9(2)), or 'restrictions' (Articles 10(2) and 11(2)). Moreover, whereas the case law of Articles 8-11 balances limiting measures vis-à-vis specific rights, Article 6(1) looks at the substance of the procedure to see whether its form was tailored as per the circumstances, i.e., with respect to exceptional, important, or relevant reasons, without needing to develop any step-by-step interpretive test that ultimately determines the legal interpretation of rights guaranteed by Article 6 . Thus, the 'closedness' of the trial in certain cases, with reference to specific conditions, remains part of the normative understanding of Article 6(1) right. 
Consequently, exception clauses allow rights to be calibrated on account of the specific terms of the relationship between the individual and public authorities, in particular special and intense relations of subjection (those characteristic of soldiers, prisoners, vagrants, mentally or physically ill), which in many cases unfold within specific institutional structures (the army, hospitals, asylums, isolation wards, social support institutions, and so on) and depend on certain forms of knowledge (military sciences, medical expertise, psychiatry and psychology, social policy and welfare discourse). Precisely which set of rights applies to one's case and what precise interpretation those rights merit depend on the specific terms of such a relationship. Calibration of rights through exceptions renders clear the limits of rights narratives that reduce rights to mere reflexes of objective law. The position in which each specific person stands in relation to the law cannot be determined in purely formal legal terms, not even by reference to the rights that stem from the specific status that person enjoys. That is why, for example, a state may train its soldiers to kill and require them to expose themselves to mortal dangers. The ECtHR has found that this does not entail either the violation of the right to life of the soldiers or forcing soldiers to violate the right to life of others. Similarly, in $X v$. Germany, the Court found that actions aiming at preventing prisoners from committing suicide were justified, even if the very same actions would, say, result in the violation of the right to liberty of persons not being imprisoned. Human rights standards do not determine, for example, why a state must possess legitimate violence at all or why imprisonment should function as a social practice. Still, and this is important to stress, human rights identify the threshold of legitimate violence by the state and the level of suffering that can be imposed through confinement.

\subsection{The case law of the ECtHR on exceptions and limitations}

The case law of the ECtHR on limitation clauses and exceptions has underlined the central role they play in the configuration of the Convention system of rights. The Court has confirmed that limitations and exceptions set rights in their socio-economic context, something which proves the flawed character of a non-political-in the sense of being pre-political, 'natural'-understanding of rights (Section 3.4.1). Moreover, limitations and exceptions are key in the democratic authorship and legitimation of rights (Section 3.4.2). Finally, limitation and exception clauses open up the definition of Convention rights to context and to the diversity of possible personal statuses, i.e., epistocracy (Section 3.4.3) and plurality and limits to rights (Section 3.4.4).

\subsubsection{Limitation clauses and exceptions prove that the ECHR rights are not pre-political rights}

When referring to both limitations and exceptions to rights, the ECtHR makes constant reference to collective and individual interests. It is indeed because legal freedoms are deemed to be both a manifestation of interests and to guard such interests ${ }^{31}$ (individual or collective) that 'balances' between rights and goods can be struck without undermining freedom. This does not necessarily result in freedom being undermined, but on the scope of freedom being determined by reference to both the substantive aspects of rights (e.g., liberty, private life, free speech) and the governmental practices that necessarily result from a specific legal-political setup (e.g., confinement, economic progress, territorial integrity). This very act of delimitation of the sphere within which individuals are actually free to act renders possible the emergence of freedom as something other than a mere individual capacity: that is, as an organising social principle. In other words, it is the guarantee of rights in conjunction with the limitations and exceptions to rights that defines freedom in legal terms. The grounding of human rights in their legal and social context through the limitation and exception clauses entails that the ECHR is based on the rejection of the pre-political

\footnotetext{
${ }^{31}$ See, e.g., Raz, above, n. 16, at 31, 176, 190-2, and M. Kramer, 'Rights Without Trimmings', in M. Kramer, N. Simmonds and H. Steiner (eds.), A Debate over Rights (Oxford University Press, 1998), at 7-11. As a conceptual tool in politics, 'interest' is assumed to be calculable (so that it can be approximated and measured), variable (so that it can be taken up, can change over time, and be abandoned) and generalisable (so that different interests can be neutralised and added up). This understanding permeates the rationale of electoral politics (so that different individual votes can be compared, substituted and statistically analysed) and the ends that a democratic polity proposes to itself (so that it can follow 'collective interests' and prevent 'sectional interests').
} 
character of rights, and consequently, of natural law theories. ${ }^{32}$ In other words, the ECHR rights can only be understood and approached by reference to a certain and specific praxis. Freedom emerges procedurally and relationally, and cannot be identified as a specific 'natural' feature of unencumbered individuals.

\subsubsection{The democratic authorship of rights}

Among all the limitations mentioned in ECHR, the test performed by the ECtHR to determine whether an interfering measure is 'necessary in democratic society' has proved to be one of the most demanding in its case law. This test has resulted in decisions in favour of the claimants' rights in a significant number of cases. ${ }^{33}$

The ECHR was forged on the assumption that the political system of all the signatory states was, and would remain, democratic. Indeed, the ECHR is premised on the foundational intertwinement of democracy and human rights. Democracy is thus characterised both as the bulwark of rights (and of the protection of the interests of rights-holders) and as a powerful ground to constrain the exercise of rights (so as to protect all rights, all genuine social and individual interests). ${ }^{34}$ In other words: on the one hand, all limits to rights are expected to be established through a democratic law-making process; on the other hand, a key set of 'limits' to the ECHR rights is to be defined by reference to what is required to uphold and sustain democracy, i.e., to the test of 'being necessary in a democratic society'.

Two socio-political effects of the intertwinement of democracy and rights are especially noteworthy.

Firstly, by considering that rights require both democratic authorship and legal determination, the ECHR affirms that democracy, and democracy only, can uphold and enforce rights. This is why the ECHR states, as democratic polities, can be acknowledged: (1) a margin of discretion in guaranteeing rights; (2) a margin of error when failing to protect rights; (3) the possibility of recalibrating the protection of certain rights (within bounds and limits) in emergency situations. Were the ECHR states to lapse in their democratic character, such margins would cease to be acknowledged (besides their very membership being imperilled). Not by chance, the former European Commission of Human Rights was not convinced when the Greek colonels invoked the state of emergency to derogate from Convention rights (cf. Denmark, Norway, Sweden, Netherlands v. Greece). ${ }^{35}$

Secondly, by construing rights as principles which underpin the functioning of democracy, the ECHR constrains democracy through the very standards that make up and define democracy. The tension between rights and democracy is inherent and internal to democracy itself, and accounts for the fact that the substantive content of rights does

\footnotetext{
${ }^{32}$ Georg Jellinek notes that 'the legal system adds something to the freedom of action of the individual, which that individual does not by nature have (der Handlungsfähigkeit des Individuums etwas hinzufügen, was es von Natur aus nicht besitzt)' (System der subjektiven öffentlichen Rechte (first published 1892, Mohr Siebeck, 2011), at 47). Importantly, Article 1 ECHR doubly challenges ascribing any natural law interpretation to the human rights the Convention protects. First, ECHR relies on the actual consent of the signatory states as 'the High Contracting Parties' to secure ECHR rights 'within their jurisdiction'. The Convention's human rights system structurally remains inactive without this prior consent or commitment. Of course, if a state withdraws its consent from the ECHR, it does not meant that it extinguishes all of its obligations based on human rights norms, but only that the Convention machinery does not apply to it. Further, Article 1 ECHR avoids referring to any idea of the human essence from which all human rights flow, unlike Article 1 of the Universal Declaration of Human Rights (e.g., reason and conscience). The ECHR simply mentions human rights; it does not justify them. The discourse of European human rights law lacks such an essentialist principle because inserting metaphysical ideas would impose one's own thick standards on the others and limit the possibility of domestic consensus on human rights. Natural law, however, relies neither on consent nor on consensus.

${ }^{33}$ Steven Greer notes: 'The phrase "necessary in a democratic society" is arguably one of the most important clauses in the entire Convention since, in principle, it gives the Strasbourg organs the widest possible discretion in condoning or condemning interferences with rights which states seek to justify by reference to one or more of the legitimate purposes in the second paragraphs of Articles 8 to 11' (The Exceptions to Articles 8 to 11 of the European Convention on Human Rights (Council of Europe Publishing, 1997), at 14). ${ }^{34}$ Ibid.

${ }^{35}$ In this sense, Article 15 ECHR presumes democracy both as a process (so that it is legitimate to invoke it when democratisation is being strengthened) and as a peculiar legal subject (so that the use of Article 15 is permitted only when the invoking state is a democratic state). In one sense, democracy is achieved by asserting itself. In another sense, democracy is saved by preventing its violent overthrow. MacDonald J notes: 'A state of emergency declared not to further democracy, but to destroy or repress it, would be invalid under Article 15' ('Derogations under Article 15 of the European Convention on Human Rights', (1998) 1-2, Columbia Journal of Transnational Law, 225, 226).
} 
not depend, as the content of ordinary law may depend, on the change of the ruling majority. The procedural structure of the ordinary law-making is presumed to generate legitimate norms, but does not by itself guarantee compliance with constitutional standards. In a narrow sense, democracy refers to a specific procedure of law and decision-making (i.e., parliamentary democracy). In a wider sense, democracy refers to a wider social setup, in which democratic legitimacy is embedded in constitutional principles, principles that have a legitimacy and stability higher to those of democratic proceduralism in a narrow sense. The ECHR relates to the second and wider conception of democracy. Therefore, even when democracy as a political procedure falters (so that rights-holders have to be protected from threatening majorities) (e.g., Refah, $\S 899,95,99,102-103$ ) or recedes (so that the courts bypass the democratic competence of the legislature) (e.g., Dudgeon, §61), the constitutional structure contains resources to uphold democracy in a wider sense. To put it differently, the rule of law, understood in a wider democratic and social sense, is not grounded on reflexive democratic law making only, but more deeply in a normative commitment to the democratic constitutional system. This is why it might become necessary to rule against procedurally enacted positive laws (as we will see in the next two sections of this essay, i.e., 4 and 5, in relation to Articles 17 and 18 ECHR).

In sum, the democratic constitutional system connects freedom with constitutional rights and democratic procedures on the one hand, and with specific collective objectives and governmental practices on the other. Autonomous moral agency becomes possible in such a 'framework of constraints', as Raz phrases it.

\subsection{3 | Epistocracy and limits to rights}

Similarly, it is important to notice that a number of the notions that are key in the drafting of limitation and exception clauses, such as 'interests of public safety' or 'protection of health', refer to established standards of scientific expertise and discourses, regulatory practices, and professional protocols. This means that it would be too simplifying to affirm that the limits to rights are set by legislative prerogative, or even for that matter, judicial prerogative. ${ }^{36}$ Reality is more complex, to the extent that such legislative and judicial interventions are determined by prevailing social standards regarding what constitutes relevant expert knowledge. By the same token, we can look at the 'margin of appreciation' that is so central in the balancing of rights and collective interests. We can see that it is reductive to conclude that this doctrine is defined by the exercise of power by the national government, without taking into account the wider socio-economic parameters crucial in the balancing act.

\subsubsection{Plurality and limits to rights}

Importantly, if practices making human rights intelligible are diverse and dissimilar, it means that the idea of autonomy is likewise heterogeneous. For example, what kind of treatment is considered as befitting an autonomous life is different in the case of, say, a mentally unstable person, a terminally ill patient, an imprisoned convict or a serving soldier. Autonomy cannot be defined obliterating such differences or, for that matter, downplaying the rationalities that define autonomy in specific contexts. Divorcing the definition of social and political freedoms from the context in which they operate fails to take the fact into account that freedom becomes meaningful only against a background of actual practices. For example, a child in a free society is autonomous when he is properly disciplined through education, and his parents are not free to deny him education at all. By the same token, identifying discursive inputs from rights-holders as the source of freedom does not capture the way regulation of subjects takes place without or against their consent, let alone their inputs. For example, in the care proceedings relating to Article 8 on the right to respect for private and family life, the idea as to what is to be understood by 'the welfare of the child' or 'child's best interests' is based on observations from national social workers, expert psychologists, teachers and welfare authorities, among others. Professional voices from particular vantage points contribute to shape the normative notions associated with autonomy. Similarly, a managerial control over lives evades being captured in discourse-based terms alone. For

${ }^{36}$ This is apart from the fact that the legislature can only address issues in their generality, which for their concrete determination fall on the judiciary. This fact makes the judicial practice of 'balancing' not only unavoidable but also expedient. It is expedient in the sense that there is no general rule of concrete limitation that in effect reduces a legal right to a nominal status. 
example, even if punishment is understood in terms of a communication theory, ${ }^{37}$ it cannot account for the rationalisation and function of, for example, supervisory observation, spatial distribution, or daily routine patterning of prisoners in a prison setup. Likewise, rights cannot be relied on to influence and eventually limit or constrain the profiling of convicts based on their crime and danger in a prison setup. Nevertheless, rights can be used to determine whether an act of profiling in a prison setup is racially discriminatory. Ironically, if a theoretical exposition of rights is not connected to the way rights become meaningful, then that theoretical exposition puts the burden of proof on the practice itself to conform to its theoretical model.

\section{4 | ABUSE OF RIGHTS: FREEDOM VERSUS RIGHTS?}

Nothing in this Convention may be interpreted as implying for any State, group or person any right to engage in any activity or perform any act aimed at the destruction of any of the rights and freedoms set forth herein or at their limitation to a greater extent than is provided for in the Convention.

Article 17 ECHR: Prohibition of abuse of rights

Limitation and exception clauses do not exhaust the complete definition of rights as a system. When making decisions based on Articles 2-16 of the Convention, the general assumption underlying the ECtHR case law is that the overall legal system is functional and compliant. With this background of structural legality, only specific instances appear a problem question, i.e., the manner in which a legal system guarantees rights, the extent to which procedural forms protect rights, the way a legitimate political system can derogate from the guarantee of certain rights during emergencies. To the extent that they do, systemic questions may come to the fore based on these articles when a legal system is unable to guarantee rights on a large scale and over an extended period of time, that is, only by implication. However, even then the guiding assumption largely remains unchanged: formal restructuration presupposes substantive commitment with rights-based norms. Consequently, in the final two articles, i.e., Articles 17 and 18 , the ECHR takes a step further. It concretises such an 'implied' understanding (i.e., consequently, the ECtHR always reads Articles 17 and 18 in conjunction with the other Convention articles), and pays attention to the eventuality that rights, or at least its discourse thereof, might be used to put in jeopardy the stability of a rights-based legal system. Thus, with Articles 17 and 18, the ECHR equips itself with standards with which the Convention organs can directly tackle wrongs of sufficient intensity and systemic nature by looking at both their formal and substantive aspects. By the help of these articles, ECHR develops standards that tell what a rights-based legal system is not, in order to protect it, and consequently acknowledges the need for legal regulation of possible systemic threats to a rights-based system. In this section, I analyse Article 17 ECHR, and, in the next one, I analyse Article 18 ECHR.

The abuse of rights and freedoms not only has to be prevented, but has to be excluded from the legal scope and remit of rights. That is the very sense and purpose of Article 17 ECHR. In collective terms, Article 17 ECHR provides tools to save democracy from its being turned into a hollow shell lethal to democracy itself: Showing abuse of rights as an anti-juridical act plays a role in preventing anti-constitutional majorities from realising their aim of dismantling constitutional democracy itself. ${ }^{38}$ In individual terms, Article 17 ECHR prevents a legal subject qua moral agent from abusing its freedom and agency. The enjoyments of the rights it abuses (to the extent that they are abused) is withdrawn (even if only temporarily, as long as that is required to defend constitutional democracy).

${ }^{37}$ C. Bennett, The Apology Ritual: A Philosophical Theory of Punishment (Cambridge University Press, 2008); D. Markel 'Retributive Justice and the Demands of Democratic Citizenship', (2012) 1 Virginia Journal of Criminal Law, 1; J. Tasioulas, 'Punishment and Repentance', (2006) 81 Philosophy, 279.

${ }^{38}$ In Vogt v. Germany, App. no. 17851/91 (ECtHR, 26 September 1995), http://hudoc.echr.coe.int/eng\#\{\%22appno\%22:[\%2217851/ 91\%22],\%22itemid\%22:[\%22001-57949\%22]\}, the ECtHR acknowledged the legitimacy of the concept of a 'democracy capable of defending itself' (\$51, 59). In Ždanoka v. Latvia, App. no. 58278/00 (ECtHR, 16 March 2006), http://hudoc.echr.coe.int/eng\#\{\% 22appno\%22:[\%2258278/00\%22],\%22itemid\%22:[\%22001-72794\%22]\}, the ECtHR interpreted Article 17 in this light (§§98-101). 
Preventing the strategic abuse of rights requires empowering public institutions so as to render them capable of tackling such wrong use of rights, while ensuring that public power is wielded in accordance with legal norms and procedures. The abuse of rights should not become in its turn an excuse for a flight from law on the side of authorities. $^{39}$ This is why the structural purpose of Article 17 ECHR is to ensure that rights are exercised within the legal context of a democratic constitutional system. This explains why Article 17 is only activated, and should only be activated, against groups or individuals whose freedom is intended to be liberticidal, which make use of the very Convention rights as one of the tools with which to erode the rule of law. Challenges that do not make use of rights, but of other means (including, quite obviously, physical force) do not come within the remit of Article 17 ECHR. The legal framework within which the state then has to react is a different one, akin to classical standards, among others such as Article 2(2) (concerning lawful deprivation of their lives) or Article 15 (concerning an extended period of their detention without trial when their members are apprehended) can be applied in such cases.

\section{1 | Syntax}

Contrary to most other articles in the Convention, no right is enshrined in Article 17; instead, the said provision affirms a key duty, which is both legal (do not abuse the rights protected by this Convention) and hermeneutical (do not misinterpret rights; do not include in the breadth and scope of the rights actions that are formally within its protective range, but substantially result in the undermining of rights). Thus, Article 17 ECHR neither protects a specific capacity of rights-holders (i.e., expression, liberty) nor requires procedural standards in view of those (i.e., fair trial, no punishment without law). As a result, one of the fundamental pillars of the architecture of European human rights law is not a right, but a 'duty'. 40

\section{2 | Invoked by}

Unsurprisingly, Article 17 is typically invoked by states against litigants that are formally rights-holders. The prohibition of the abuse of rights reverses the standard normative relation governed by the ECHR. Article 17 protects the legal system of human rights as a whole as well as specific Convention rights from rights-holders with a view to safeguard the democratic constitutional system. For example, in United Communist Party of Turkey v. Turkey, the ECtHR identified five broad criteria when the right to association may be abused through the creation and maintenance of a political party: (1) The party is not a democratic party proper because 2) the party resorts to illegal or undemocratic methods, 3) encourages the use of violence, 4) aims at undermining the democratic and pluralistic political system, 5) pursues objectives that are racist or likely to destroy the rights and freedoms of others (§23; cf. German Communist Party, at 4).

\footnotetext{
${ }^{39}$ See, Glimerveen and Haagenback v. the Netherlands, App. no. 8438/78 (ECmHR, 11 October 1979), http://hudoc.echr.coe.int/ eng\#\{\%22appno\%22:[\%228348/78\%22]\}, at 187.

${ }^{40}$ For Kelsen, 'the right in the specific sense of the word is the legal power to enforce an existing duty' General Theory of Norms (Oxford University Press, 1991), at 324. This definition of right assumes an already existing normative justification to protect an action or an object, and a legal power that enforces those standards aptly. Therefore, rights have a relational character. Consequently, there already exists a possibility of governability of relations construed in legal terms. However, one's status as a subject of rights, within the legal system, is itself premised on a basic duty. This duty imposes an obligation as enshrined in, for example, Article 17 ECHR. Therefore, as a condition of possibility, human rights are premised on a duty that a subject of right owes both to oneself as a holder of rights and to the legal system. To the extent that the human rights system remains premised on such a duty, and to the extent that Article 17 ECHR and Article 30 of the Universal Declaration mention it, this moral duty understood in legal terms remains conceptually nested with the idea of rights as entitlements, i.e., which set of rights I am entitled to depends on my conduct vis-à-vis the aforementioned duty.
} 


\subsection{Drawing the line between misuse and abuse of rights}

The tension between the affirmation of autonomy and the curbing of autonomy to safeguard it calls for a delicate balancing act. This accounts for Article 17 having been constructed as aiming at preventing the 'complete' subversion of human rights, ${ }^{41}$ not any action that may, even slightly, affect the wholeness of rights. As noted in Paksas v. Lithuania, Article 17 activates only 'on an exceptional basis and in extreme cases' (§87).

\subsection{How it has to be constructed}

The effectiveness of the prohibition of the abuse of rights depends, however, on the article being constructed in an open-ended fashion, in the particular sense of serving as a complement to the meaning of all other substantive articles of the Convention. Article 17 is in itself a 'negativity' to be read in conjunction with each of the other substantive Convention articles. The purpose of Article 17 is to complement the full legal meaning of all other articles. This is the case, for example, when the limitations of an article with which Article 17 is read in conjunction are considered to be limiting, and there is nevertheless an acknowledgment that that right is being utilized for ends 'contrary to the text and spirit of the Convention' (Marais v. France, at 190). In such a way, Article 17 operates as a fundamental check over the use of various fundamental rights. In particular, individuals and groups with liberticidal aims are prevented 'from exploiting in their own interests the principles enunciated in the Convention' (Paksas v. Lithuania, §87). Wherein such an aim does not exist, the ECtHR does not apply Article 17. This can be illustrated by the companion case Paksas v. Lithuania, regarding a former Lithuanian President who had been impeached and disqualified from holding elected office for life after being condemned on several accounts for cronyist behaviour. The ECtHR stated that Article 17 could not be invoked by the (new) Lithuanian authorities, because the underlying conduct (of the former President), even if reproachable, did not aim at subverting the system of rights (§89).

\section{5 | Beyond balancing}

There is no balancing in the case law on Article 17. Its 'negative' character entails that there are no limitations or exceptions. It takes two not only to tango, but also to balance. The normative force of Article 17 is not employed to determine in what manner the legal interference of rights is to take place, but rather to determine what has been interfered with. ${ }^{42}$ Thus, in those cases where Article 17 is applied, the legal decision is, comparatively speaking, not detailed. ${ }^{43}$ As such, the logics of freedom reach their conceptual and practical limits when they confront the essence of unfreedom. ${ }^{44}$

\subsection{Implications: Not only formally valid, but also substantively valid}

Article 17 ensures that the exercise of each right is not simply legally but also normatively valid. This connects each article of the Convention enshrining a fundamental right with the normative order of a free society. Therefore, the scope of difference that each fundamental right promotes and guarantees stays within a 'uniform' framework of plurality-akin in effect but not in rationale to Rawls's idea of 'reasonable pluralism'.

\footnotetext{
${ }^{41}$ Since Article 17 is to be used in order to prevent a subversive use of the Convention rights, it cannot be utilised by state authorities for those reasons which the Convention does not explicitly refer to; see United Communist Party v. Turkey, App. no. 19392/92 (ECtHR, 30 January 1998), http://hudoc.echr.coe.int/eng\#\{\%22fulltext\%22:[\%2219392/92\%22]\}, §60.

${ }^{42}$ D. Keane, 'Attacking Hate Speech under Article 17 of the European Convention on Human Rights', (2007) 25 Netherlands Quarterly of Human Rights, 641, 643, 656.

${ }^{43}$ Whereas the case law of Articles 8-11 relies on the notions of balancing and discretion, when these articles are read in conjunction with Article 17, the exercises relating to balancing and discretion reach their judicial limit.

${ }^{44}$ Therefore, for Cannie and Voorhoof, Article 17 generates a 'guillotine effect'. See their, 'The Abuse Clause and Freedom of Expression in the European Human Rights Convention', (2011) 29 Netherlands Quarterly of Human Rights, 54, 58.
} 
Further, those individuals and groups that combat a legal system by abusing their rights find their enjoyable set of legally guaranteed rights reduced in view of their moral 'rightness'. Importantly, however, it means that the activation of Article 17 does not throw one against whom this article is invoked out of the legal context. That is in the sense that all of its legal protections are withdrawn (Glimmerveen, at 195). In W.P. and Others v. Poland, for example, the ECtHR dealt with a complaint against the Polish government for banning a racist and anti-Semitic association entitled 'National and Patriotic Association of Polish Victims of Bolshevism and Zionism'. In it, the ECtHR noted that to achieve Article 17's purpose, it was not 'necessary to take away every one of the rights and freedoms guaranteed from persons found to be engaged in activities aimed at the destruction of any of those rights and freedoms' (W.P. and Others, The Law). Thus, Article 17 only causes that subject (party, individual, group) to lose those rights that protect its specific capacity, such as association, thought or expression. Only those capacities that abuse rights are, so to speak, 'neutralised' (Lawless v. Ireland, 1, 13, 15). ${ }^{45}$ It also means that a holder of rights does not lose non-derogable rights. ${ }^{46}$

Importantly, Article 17 ensures that when a rights-holders abuses its rights by interpreting them unreasonably, it is human rights itself which requires circumscribing its capacity to act. This entails that the abuser remains through and thoroughly a rights-holder. Article 17 identifies the set of rights that one is entitled to depending on one's conduct, without conditioning the very status as rights-holder. The calibration of the scope of action is undertaken by reference to statements, actions and manifestations, and participation in organised social practices ${ }^{47} .{ }^{48}$ For example, in the German Communist Party case, the former Commission noted that the party itself spoke of 'the dictatorship of the proletariat' (at 3). Therefore, its establishment and organisation constituted an activity within the meaning of Article 17 (at 4). This fact in itself made invocation of Articles 9, 10 and 11 redundant. Resultantly, Article 17 ensures that rights are exercised by subjects in a manner that their exercise remains generalisable within the context of human rights. Thus, Article 17 is important in the framework of the ECHR because it ensures the continuity of a legal system that the ECHR establishes in the face of contingency and behavioural unpredictability.

\section{7 | Pre-emptive character}

Furthermore, unlike others articles, Article 17 is pre-emptive (Glimerveen, at 196). This means that Article 17 can be used to withdraw the protective capacity of specific rights. This occurs at a time when the content of an act is troublesome, albeit the subject is within an ostensible legal threshold (Glimerveen, at 190; German Communist Party, at 4). In German Communist Party, for example, 'the dictatorship of proletariat' had not been established.

\footnotetext{
${ }^{45} \mathrm{As}$ far as the case law of Article 17 is concerned, it has been relied on only to withdraw those rights that 'have been deflected from their real purpose' (Paksas v. Lithuania, App. no. 34932/04 (ECtHR, 6 January 2011), http://hudoc.echr.coe.int/eng\#\{\%22appno\%22: [\%2234932/04\%22],\%22itemid\%22:[\%22001-102617\%22]\}, §88): the right to freedom of thought and opinion (Kühnen v. Germany, App. no. 12194/86 (ECmHR, 12 May 1988), http://hudoc.echr.coe.int/eng\#\{\%22fulltext\%22:[\%2212194/86\%22]\}), expression (Schimanek v. Austria, App. no. 32307/96 (ECtHR, 1 February 2000), http://hudoc.echr.coe.int/eng\#\{\%22appno\%22:[\%2232307/ 96\%22],\%22itemid\%22:[\%22001-24075\%22]\}, Pavel Ivanov v. Russia, App. no. 35222/04 (ECtHR, 20 February 2007), http://hudoc. echr.coe.int/eng\#\{\%22appno\%22:[\%2235222/04\%22],\%22itemid\%22:[\%22001-79619\%22]\}), or association (Hizb-ut Tahrir v. Germany, App. no. 31098/08 (ECtHR, 12 June 2012), http://hudoc.echr.coe.int/eng\#\{\%22appno\%22:[\%2231098/ 08\%22],\%22itemid\%22:[\%22001-111532\%22]\}).

${ }^{46}$ 'Only four rights in the Convention are absolute in the sense that their suspension or restriction can never be justified: the right not to be subjected to torture or to inhuman or degrading treatment or punishment (Article 3); the right not to be held in slavery or servitude (Article 4(1)); the right not to be convicted for conduct which was not an offence under national or international law at the time it occurred (Article $7(1)$ ) and the right not to have a heavier penalty imposed for an offence than the one applicable at the time the offence was committed (Article 7(1))' (S. Greer, above, n. 33, at 44-5).

${ }^{47}$ Cf. Kühnen, above, n. 45, The Facts; Schimanek, above, n. 45, The Facts.

${ }^{48}$ The first signs of such liberticidal aims can be discerned at the level of expression. Thus, in a large number of cases, Article 17 has been activated to remove the protection of Article 10 on the right to freedom of expression. This is especially so when a remark is explicitly 'directed against the Convention's underlying values' (Paksas, above, n. 45, §88).
} 
As such, Article 17 is theoretically central in another sense. It explicitly gives the positive legal system a strong normative basis. Thus, an application of Article 17 goes beyond any abstraction that positive law does from the kind of motivation in order to gauge legal conformity. As such, the case law of Article 17 is not simply limited to being contented with protecting a law-abiding behaviour. Consequently, Article 17 can be relied on before a liberticidal individual or group increases its socio-political influence enormously. In fact, one of the crucial tasks that the drafters of the ECHR faced, and consequently the aim that Article 17 importantly tries to realize, was to block the resurgence of liberticidal leaders and groups. ${ }^{49}$ In other words, a political consciousness of temporality guides Article 17. If the threat, however, becomes alarming, a democratic constitutional state, and that alone, can utilise Article 15 in order to derogate from the guarantee of certain rights, while declaring an emergency.

\section{8 $\quad$ Distinction between abuse and misuse of rights}

Article 17 is seldom found to be applicable after a threat has subsided or has been overcome (De Becker, Report of 8 January 1960, Series B No. 2, 137-138). Very telling in that regard is Lehideux and Isorni v. France. In that case, the ECtHR rejected constructing the limits of freedom of the press through the perspective of Article 17, contrary to what the French authorities had done when the leading French daily Le Monde had published an article defending a rather revisionist account of Pétain's role in the Vichy regime. Characterising the publication as an abuse of rights failed to consider the fundamental role of time and timing in the application of Article 17. The Court noted that 'the lapse of time makes it inappropriate to deal with such remarks, forty years on, with the same severity as ten or twenty years previously' (§55).

\subsection{Edging behaviour back to the Convention}

Article 17 has been interpreted by the ECtHR as favouring individuals or groups moving back into the sphere of protection of the ECHR. The ruling in Kühnen, for example, may be constructed as an invitation to drop references to a revolutionary overthrow of the State and the establishment of a dictatorship of proletariat from the political agenda of a political party. ${ }^{50}$ This reconciles the prohibition of the abuse of rights to undermine the

\footnotetext{
${ }^{49}$ The preparatory notes of Article 17 ECHR clearly pinpoint the aim of its drafters: developing standards that would legally regulate abuses of rights and freedoms before it is too late. As a drafter of Article 17, Maxwell-Fyfe remarked: 'We do not desire by sentimentality in drafting to give evilly disposed persons the opportunity to create a totalitarian government which will destroy Human Right altogether', http://www.echr.coe.int/LibraryDocs/Travaux/ECHRTravaux-ART17-CDH(75)7-BIL1338904.pdf, at 3. In his concurring opinion in Lehideux, Judge Jambrek influentially noted: 'The European Convention was drafted as a response to the experience of world-wide, and especially European, totalitarian regimes prior to and during the Second World War. One of its tasks was, according to Rolv Ryssdal, to "sound the alarm at their resurgence"' (§3). Despite the validity of this observation, the source cited does not contain any such quote from Ryssdal (see, R. Ryssdal, 'The Expanding Role of the European Court of Human Rights', in A. Eide and J. Helgesen (eds.), The Future of Human Rights Protection in a Changing World (Norwegian University Press, 1991), 115). Be as it may, in Refah Partisi v. Turkey, App. no. 41340/98 (ECtHR, 13 February 2002), http://hudoc.echr.coe.int/eng\#\{\%22appno\%22: [\%2241340/98\%22],\%22itemid\%22:[\%22001-60936\%22]\}, the ECtHR noted: 'A State cannot be required to wait until a political party has seized power and begun to take concrete steps to implement a policy incompatible with the standards of the Convention and democracy, even though the danger of that policy for democracy is sufficiently established and imminent' (\$102).

${ }^{50}$ In certain cases, this may cause anti-constitutional elements to be duplicitous and ambiguous. What is academically required at such moments is to analyse the manner through which their apparently legal conduct is conceptualised. For a relevant case study, one can look at the political repercussion of Jörg Haider's far-right Austrian Freedom Party (Freiheitliche Partei Österreichs), which was included in the Austrian cabinet when it gained $26.9 \%$ of the votes in the general elections of 1999 . Subsequently, there was an instalment of diplomatic sanctions against Austria by the EU. However, the report of the panel appointed by the ECtHR monitoring Vienna's human rights record was decisive in ending the sanctions. Similarly, a recent judgment by the German Constitutional Court that blocked the ban on extreme right-wing National Democratic Party (Nationaldemokratische Partei Deutschlands) is interesting because of its focus on the issue of public opinion and general influence. The Court believed that on the both these counts, NPD did not stand any chance to succeed. Things would have been otherwise, had NPD been influential. In other words, it also means that when human rights meet a political limit, it becomes less of righteous government of men and more of government of righteous men.
} 
Convention with the tolerance of arguments regarding the desirability of the very content of the Convention. It is because of this tricky balancing act that Article 17 stands in an inverse relation with the social effectiveness of human rights norms: the lesser the number of cases in which states 'win' on the basis of Article 17, the more socially effective human rights norms are likely to be in the guidance of conduct in society.

\subsection{0 | Bridge to next section}

The regulation of freedom necessarily includes the prohibition of certain courses of 'free' action on the basis of a proper consideration of the full context of such actions. In this section, I have claimed that Article 17 plays a fundamental role in that regard, by signalling to rights-holders what they cannot do on the basis of the very rights that constitute their agency in legal terms. Whereas limitations and exceptions to rights define the shape of freedom, Article 17 defines the essence of (un)freedom. In the next section, I consider the other 'dark' side of rights, the 'statal' equivalent of abuse of rights. National authorities may make use of rights and rights discourses in ways that render the legal and political system (increasingly) antithetical to the effective enjoyment of rights. Article $18 \mathrm{ECHR}$ is intended to prevent this from happening by limiting the very limits that states can impose on rights.

\section{I HUMAN RIGHTS AND STATE POWER: A PRIMORDIAL IF AGONISTIC RELATIONSHIP}

The restrictions permitted under this Convention to the said rights and freedoms shall not be applied for any purpose other than those for which they have been prescribed.

Article 18 ECHR: Limitation on use of restrictions on rights

So far, I have shown how the full definition of rights depends on clauses that restrict the scope of freedom of rights-holders in order to uphold a rights-based legal system. In the process, I have stressed the extent to which rights depends on the executive and administrative capacities of states. Sections 2 and 3 made clear the extent to which institutionalised collective action through the state makes possible the legally mediated realisation of freedom. In this section, I will consider the 'dark side' of the centrality of the state in the protection of rights. If in abstract terms the state is called to become the champion of rights, the force and power of the state may result in the undermining of rights. This calls for law closing the full definition of rights by means of limiting the very limiting and excepting actions of the state. This is the structural role played by one of the fundamental provisions of the Convention, Article 18 ECHR. $^{51}$

Article 18 ECHR limits the discretion of public authorities when restricting the scope of Convention rights. ${ }^{52}$ As is also the case with Article 15 ECHR (empowering public authorities to calibrate the remit of rights during emergencies), Article 18 ECHR stands out on account of it explicitly addressing not rights-holders but public

\footnotetext{
${ }^{51} \mathrm{~A}$ widely read textbook, for example, wonders: 'It is not clear why Article 18 was included in the Convention. There is no equivalent provision in the Universal Declaration of Human Rights ... There is not much guidance in the preparatory work. Article 18 may seem to add little to the Convention except to make explicit what is either implicit in other provisions or may be thought to be well established under the general principles recognised by international law' B. Rainey, E. Wicks and C. Ovey, Jacobs, White, and Ovey: The European Convention on Human Rights (Oxford University Press, 2014), at 124.

${ }^{52}$ In The Greek case, App no. 3321-3/67, 3344/67 (ECmHR, 24 January 1968), http://hudoc.echr.coe.int/eng\#\{\%22fulltext\%22: [\%223321/67\%22],\%22itemid\%22:[\%22001-3049\%22]\}, Article 17 was invoked by the applicant states against the use of Article 15 by the Greek colonel junta. However, the ECmHR decided against the derogation, and did not consider Article 17 as being useful to analyse the case. Albeit in this case the Commission did not read Article 15 in conjunction with Article 17, it did not rule out a possibility for such an analysis.
} 
authorities. ${ }^{53}$ As far as the latter is concerned, the result is the limitation of the restricting powers of public authorities. While the argumentative burden rests with the eventual individual plaintiff, Article 18 ECHR makes clear that the setting of limits and exceptions to rights in the Convention does not imply extending a blank cheque to Convention states. Freedom can and must be restricted in order to ensure the wholeness of the system of rights. The limitations and exceptions foreseen in the ECHR constitute the clear set of rationales for that purpose. Limitations and exceptions actually undertaken for other reasons constitute actual breaches of Convention rights. $^{54}$ In plain English, there may well be instances in which actions that public authorities claimed constituted legitimate limitations to rights should not be regarded as such, but as violations of rights. ${ }^{55}$

\subsection{The text in its context}

Article $18 \mathrm{ECHR}$ results from the tension between the general and abstract characterisation of public authorities as the guarantor of Convention rights and the concrete and, so to say, contextual possibility that specific public authorities may either breach Convention rights or, hopefully only exceptionally, may be willing to become their nemesis. It is indeed the concrete and historical 'state' that is occasionally condemned on the basis of Article 18 ECHR. Indeed, the ECtHR, even if declaring the responsibility of the state, focuses on the specific actors within the machinery of the state responsible for the breaches. ${ }^{56}$

This gap requires keeping under constant scrutiny the substance and quality of state action. Review of state action demands going beyond the procedural forms and the arguments that may be invoked by the state, or what

${ }^{53}$ Thus, the implementation of rights remains sensitive to the factual and situational circumstances, while rights bring the form of the legal guarantor in line with their normative content. Importantly, this fact limits the application of the conceptual lens of human 'dignity' (or related concepts that one would rather understand in essentialist terms) to analyse the case law of ECHR systematically because Articles 15 and 18 talk about discretion and obligations of a legal entity that is not a human and which, as a complex of institutional structures, does not possess itself any human 'dignity' as such. Crucially, Roman law spoke of the dignitas hominis of the Roman state, office-holders, patricians and the like, and punished Romans accordingly. Thus, as many commentators have pinpointed, the idea of human dignity is conceptually and analytically different from that of the Roman idea of dignitas hominis because the latter remained connected: (a) with the honour of certain statuses, (b) with what law should give to those legal subjects depending on what they deserve, and (c) was additionally applicable to inanimate entities that were neither natural persons nor reducible to them, i.e., the state. Be that as it may, Article 15 ECHR limits the enforcement of certain fundamental human rights by permitting public authorities to justifiably derogate from their guarantee, and resultantly divides the concept of human 'dignity' into two halves, i.e., in an expansive sense and in its core sense, which corresponds to derogable and non-derogable rights. However, even non-derogable rights do not apply to everyone in plain, categorical terms (see, sections 4.1, 4.4, 4.6). Moreover, Article 18 ECHR works through double negation. If 'dignity' affirmatively grounds rights and freedoms, then limitation and exception clauses contextualise rights and freedoms, and consequently define what we are not to understand by 'dignity' only in abstract terms. Then, Article 18 ECHR limits the discretion of a legal guarantor of rights with respect to the legitimate breadth of limitation clauses, while moving a step away from the concept of 'dignity', because the application of Article 18 understands the violation of rights with respect to its proper limitations and the use of Article 18 entails that a limiting act did not fall in line with the limitation clauses and only this, as a consequence, leads to the violation of Article 18. Now, if one instead analyses limitations and exceptions to rights on the basis of 'dignity', the possibility of deriving the basis of all rights and freedoms affirmatively from the very same concept appears tautological, or, in other words, the same concept cannot ground both what things are, what their limits are, what limits are imposed on them, and what they are not, without losing its analytical clarity. Or, one can instead argue that 'dignity' rather signifies loosely, and broadly, what lawyers call, following Aristotle (Politics, 1213), a 'legal intuition' (Radbruch's 'Rechtsgefühl'). However, without grounding legal intuitions contextually within governmental practices, institutional structures and legal norms that articulate those intuitions, one's analysis of the ECHR case law using such a concept would remain anything but coherent, or, what amounts to saying the same thing, analytical coherence forces intuitively obtained concepts to shed their essentialist form and to merge with the context from which they appear to emerge in the first place.

${ }^{54}$ See Khodorkovskiy v. Russia, App. no. 5829/04 (ECtHR, 31 May 2011), http:// http://hudoc.echr.coe.int/eng\#\{\%22appno\%22: [\%225829/04\%22],\%22itemid\%22:[\%22001-104983\%22]\}, §260; and, Gusinskiy v. Russia, App. no. 70276/01 (ECtHR, 19 May 2004), http://hudoc.echr.coe.int/eng\#\{\%22appno\%22:[\%2270276/01\%22],\%22itemid\%22:[\%22001-61767\%22]\}, §77.

${ }^{55}$ Gusinskiy, above, n. 54, §§73, 75.

${ }^{56}$ While mentioning in Gusinskiy (above, n. 54) the role of prison authorities, Acting Minister for Press and Mass Communications, and a State investigating officer in intimidating the applicant (\$76), court decisions involving Article 18 do not find the state per se to be in the wrong. Only specific individuals working in the state machinery-not the general signifier of the State-are seen as a causal factor, even if this may resultantly give the state, from a legal perspective, a 'transcendent' status. 
is the same, consider the substantive implications of the actual actions of the state, so to say, underneath the legal form in which they are clothed. Article $18 \mathrm{ECHR}$ sets the framework under which it is possible to check whether governmental practices serve their declared purpose and unfold according to proper procedures. In Gusinskiy v. Russia, for example, a violation of Article 18 was found to have occurred, when a Russian media tycoon who owned a private media company, i.e., Media Most, was arrested and detained on charges of fraud. The applicant was released on the basis of 'agreement' with Russian authorities while he was placed in detention by the same authorities: that charges against him would be dropped if he sold Media Most to Gazprom, a giant conglomerate controlled by the Russian state, at a price determined by Gazprom. The ECtHR noted that 'it was not the purpose of such publiclaw matters as criminal proceedings and detention on remand to be used as part of commercial bargaining strategies. ${ }^{57}$ To put it differently, the explicit enshrinement of Article 18 ECHR was intended to reduce the chances that the legal apparatus be used as a tool to breach Convention rights. ${ }^{58}$

Thus, it is based on an absence of following established practices (such as: investigation methods, detention procedures, use of the concept of 'reasonable suspicion', legal safeguards) through which the interferences with rights are permitted under the ECHR that Article 18 is activated (Cebotari v. Moldova, §48). Thus, it is based on the manner in which those measures are modified that a State may legally limit rights under law and accrue legitimacy onto itself in the process. By looking at those practices, Article 18 ensures that the political relationship that human rights require between its own normative standards and a concrete legal-political guarantor is aptly maintained. The aptness that Article 18 maintains stands in between the exception and the limitation clauses (the legal room the ECHR provides to a state by acknowledging necessities relating to its monopoly of legitimate violence) and the right to derogation (the legal room the ECHR provides to a State by acknowledging necessities relating to an emergency).

As much as is the case with Article $17 \mathrm{ECHR}$, as pointed out above, Article $18 \mathrm{ECHR}$ does not have a substance of its own, but has to be applied and implemented jointly with other sections of the Convention. ${ }^{59}$ In particular, Article 18 ECHR review brings into play the unwritten 'spirit of the Convention'. ${ }^{60}$ Such an unwritten spirit cannot be articulated in an exhaustive manner, but still remains a fundamental resource by reference to which the ECtHR characterises state actions and decisions as incompatible with the Convention.

\subsection{Referring facts back to norms}

The structural effect of Article $18 \mathrm{ECHR}$ is that of completing the set of legal resources that the ECtHR can mobilise when confronted with state breaches of rights justified in the name of upholding the very same rights. While quite obviously there is a political dimension to such a state of affairs, Article 18 ECHR allows the issue to remain a fully legal one, or, what is the same, provides an explicit basis on which such infringements can be tackled within strictly legal discourse. In other words, Article 18 draws a legal, and not merely political or moral, line between compliance with rights and manipulation of rights with a view to infringe them. ${ }^{61}$

It is important to add that while Article 18 adds a fundamental layer of protection against the subversion of rights 'from within', that is, protects rights from public authorities breaching them under the false cover of protecting them, the Convention system of rights cannot but assume that in most cases public authorities are a champion, not the

${ }^{57} \$ 76$.

${ }^{58}$ Cf. Ilgar Mammadov v. Azerbaijan, App. no. 15172/13 (ECtHR, 22 May 2014), http://hudoc.echr.coe.int/eng\#\{\%22appno\%22: [\%2215172/13\%22],\%22itemid\%22:[\%22001-144124\%22]\}, §137; Sisojeva v. Latvia, App. no. 60654/00 (ECtHR, 15 January 2001), http://hudoc.echr.coe.int/eng\#\{\%22appno\%22:[\%2260654/00\%22],\%22itemid\%22:[\%22001-79022\%22]\}, §129).

${ }^{59}$ Thus, in certain cases, Article 18 can be violated even when the article in conjunction with which it is read is not (cf. Gusinskiy, above, n. 54, §73; Cebotari v. Moldova, App. no. 35615/06 (ECtHR, 13 November 2007), http://hudoc.echr.coe.int/eng\#\{\%22appno\%22: [\%2235615/06\%22],\%22itemid\%22:[\%22001-83247\%22]\}, §49).

${ }^{60}$ Lutsenko v. Ukraine, App. no. 6492/11 (ECtHR, 19 November 2012), http://hudoc.echr.coe.int/eng\#\{\%22appno\%22:[\%226492/ 11\%22],\%22itemid\%22:[\%22001-112013\%22]\}, §108.

${ }^{61}$ lbid., §§104-110; Tymoshenko v. Ukraine, App. no. 49872/11 (ECtHR, 30 April 2013), http://hudoc.echr.coe.int/eng\#\{\%22appno\% 22:[\%2249872/11\%22],\%22itemid\%22:[\%22001-119382\%22]\}, §299. 
nemesis, of rights. In other words, Article 18 cannot be an effective means of creating or recreating a constitutional culture of rights protection. If Article 18 protects such a culture, it only does to an extent by presupposing its importance and preventing actions that would rather end it.

\subsection{Avoiding the distortion of rights in the name of protecting them}

In sum, Article 18 ensures that the legal apparatus on whose effectiveness and 'good faith' the Convention depends (Khodorkovskiy v. Russia, §255; Tymoshenko v. Ukraine, §294) does not justify the distortion of rights in the name of their protection (Gusinskiy v. Russia, §76). The obligation Article 18 imposes is that a legal guarantor of rights should respect the authoritative room that human rights norms gives it. Therefore, when the ECtHR notes in Gusinskiy (§§73-76) that the applicant's liberty was restricted for a purpose other than that provided for in Article 5(1c), the ECtHR delimits the margin of discretion accorded to authorities. This means that limitation and exception clauses not only address rights-holders, but also a state. By doing so, Article 18 constrains, within the limitability of the aforementioned clauses, the legal systems on which human rights depend. In other words, Article 18 points to an important fact: if there are modalities of power (e.g., political, legal, administrative) that are to be utilized in order to establish an order of freedom (i.e., democratic constitutional system), then that system has to remain cognizant of the workings of power on which it relies. This is because the latter are never risk-free. The negative conditions that define such system, emerge from within it, and the way they are dealt with constitute the negative governmentality of human rights. It is to the final recapitulation of this concept that the next section turns.

\section{I CONCLUDING REMARKS}

I analysed how freedoms are interpreted in the background of a praxis. I argued that practices of autonomy already presuppose limitations and exceptions to rights (Section 2). This entails that rights are defined not only by affirmative statements but also, and crucially, by the limitations and exceptions to the very same rights. I then analysed why and in which sense an autonomous moral agent is not free to do away with freedom (Section 3). Rights provide their holders with the resources to contest legal and political decisions. However, rights cannot be constructed as enabling rightsholders to contest the very existence of the rights on which they stand. This led us to consider the extent to which rights empower public authorities by identifying what the state cannot do by reference to the principles underpinning rights (Section 4). Finally, I claimed that all these dynamics are theoretically interconnected. Negative governmentality is placed at the crossroads where all of them meet, to the extent that what is of essence is what cannot be done through freedom. The negative side of rights is indeed what makes a system out of the congeries of legal norms, and what defines the law as a guide of conduct. Defining rights as privileges, as is implicit in many contemporary legal and constitutional theories (including mainstream theories of EU law) is simply (and utterly) wrong. It is impossible to be a rights-holder without bearing certain duties and, more deeply, without implicitly assuming, in a certain Razian manner, the ethics of autonomy.

The reconstruction of the law of the European Convention on Human Rights illustrates the theoretical points made in this article. On the basis of a detailed analysis of the 'negative' clauses of the ECHR, I showed that these often neglected norms turn the ECHR into a genuine legal system. The sections here studied not only form an integral part of the Convention, but more importantly, function as certain limit-concepts that play a decisive role in determining the actual substantive content of rights in critical situations, in the very cases in which the role of rights is tested to its limits. It is at these critical junctures that the fate of the human rights system is ultimately determined.

How to cite this article: Nasir MA. Negative governmentality through fundamental rights: The far side of the European Convention on Human Rights. Eur Law J. 2018;24:297-320. https://doi.org/10.1111/eulj.12242 